\title{
HUBUNGAN ISLAM DAN NEGARA: Merespons Wacana Politik Islam Kontemporer di Indonesia
}

\author{
Hamsah Hasan \\ Institut Agama Islam Negeri (IAIN) Palopo Sulawesi Selatan \\ e-mail: hamzahtawang@yahoo.com
}

\begin{abstract}
This article aims to discuss the issues of the relationship between Islam and state in the Islamic political perspective in Indonesia. This study was motivated by the desire to criticize the development and "up and down" relationship between Islam and state that is very dynamic coloring political situation in "Islamic majority country" Indonesia. This article concluded that understanding the relationship between religion and state with Islamic political approach is not meant to establish a religious state or an Islamic state of Indonesia, but more on filling spaces are functionally religion in order society, nation and state. The relationship between Islam and state can be integrated in a functional relationship equally aspire to nobility. Even integralistic, symbiotic, and secularistic relations, each should be viewed as a form of complementary. Facing the development of modernization, the relationship between Islam and state should be articulated as an effort to always adapt to the development of society in its various aspects, such as: the globalization of the world political economy, science and technology, the development issues of democracy, gender, human rights, pluralism, both nationally and internationally.
\end{abstract}

[]

Artikel ini bertujuan untuk mendiskusikan kembali isu tentang hubungan Islam dan negara dalam perspektif politik Islam di Indonesia. Kajian ini dilatarbelakangi oleh keinginan untuk mengkritisi perkembangan serta pasang-surut hubungan Islam dan negara yang sangat dinamis mewarnai peta perpolitikan di Indonesia yang kental dengan tradisi Islam. Pembahasan ini menyimpulkan bahwa: Pemahaman terhadap hubungan agama dan negara dengan pendekatan politik Islam tidak dimaksudkan untuk mendirikan negara agama atau negara Islam Indonesia, tetapi lebih pada pengisian ruang-ruang agama secara fungsional dalam tatanan kehidupan bermasyarakat, berbangsa dan bernegara. Hubungan Islam dan negara dapat terintegrasi dalam sebuah relasi fungsional yang sama-sama mencita-citakan keluhuran. Baik relasi integralistik, simbiosis maupun sekularistik, masing-masing harus dipandang sebagai bentuk yang saling melengkapi. Menghadapi perkembangan modernitas, hubungan Islam dan negara harus diartikulasikan sebagai upaya untuk selalu menyesuaikan dengan perkembangan masyarakat dari berbagai aspeknya, seperti: globalisasi ekonomi-politik dunia, sains dan teknologi, perkembangan isu-isu demokrasi, gender, HAM, pluralisme, secara nasional maupun internasional.

Keywords: relasi Islam dan negara, politik islam, integralistik, sekularistik 


\section{Pendahuluan}

Pembahasan tentang hubungan Islam dan negara telah banyak dibahas para ahli di dunia Islam seiring munculnya konsep nation state (negara bangsa) pada abad ke-19 yang dipopulerkan oleh dunia Barat ke dunia internasional, termasuk wilayah Indonesia yang berpenduduk mayoritas Islam. Meski konsep nation state telah diperkenalkan sejak awal abad ke-19, pada umumnya persoalan Islam dan negara baru serius menjadi isu internasional -tak terkecuali di negara-negara berpenduduk mayoritas Islam seperti Indonesia- pada tahun 1940-an di abad ke-20 lalu, tepatnya pada pasca perang dunia kedua.

Setelah Indonesia memproklamirkan kemerdekaannya pada tahun 1945, dan kemudian mendapat pengakuan dunia internasional secara de jure dan de facto, sejak itu pula gencar didiskusikan masalah Islam dan negara. Namun demikian, secara historis sebenarnya telah dimulai sejak pra kemerdekan. Di masa pasca kemerdekaan inilah relasi wacana Islam dan negara secara formal menjadi pembahasan di lembaga-lembaga dan organisasi pemerintah maupun non pemerintah, partai-partai, ormas-ormas, dari level organisasi dan lembaga kecil hingga lembaga-lembaga tinggi negara baik lembaga eksekutif, legislatif maupun yudikatif.

Menarik dicermati pola-pola pemikiran politik Islam dalam kaitan dengan perseteruan Islam dan negara pasca kemerdekaan, di mana sebagian kalangan memandanganya sebagai sikap moderat umat Islam Indonesia di masa itu. Oleh karena itu, banyak kalangan melihat sebagai "kesuksesan" para tokoh Islam melahirkan falsafah dasar negara yaitu Pancasila melalui deklarasi Piagam Jakarta tahun 1945. Meski demikian, harus diakui bahwa tidak sedikit juga yang menilai hal tersebut sebagai "kegagalan" ulama atau tokoh pergerakan Islam dalam perumusan final Piagam Jakarta, terutama terkait dengan penghapusan sembilan kata dalam sila pertama Pancasila yaitu "ketuhanan dengan kewajiban menjalankan syariat Islam bagi pemeluk-pemeluknya", yang kemudian berubah menjadi empat kata yaitu sila "Ketuhanan Yang Maha Esa". ${ }^{1}$ Inilah antara lain hasil dari berbagai dialog dan diskusi panjang, penuh

\footnotetext{
${ }^{1}$ Sila 'Ketuhanan Yang Maha Esa” diyakini sebagai sila yang terpenting dalam ajaran Islam. Karena itu Harun Nasution menyatakan bahwa benarlah ulama dan pemimpin Indonesia yang mengatakan 
kemelut dan melelahkan umat Islam Indonesia pasca kemerdekaan dalam menyikapi tema "relasi Islam dan negara".

Dalam perkembangannya, gagasan tentang negara Islam, muncul setelah pemilihan umum tahun 1955. Ketika itu, dalam kondisi demokrasi parlementer yang berkembang semenjak tahun 1950-an, Dewan Konstituante diberi kesempatan untuk menyusun UUD baru, yang protagonisnya adalah Mohammad Natsir. Kondisi ini dapat dipahami, ketika tahun 1950-an pegerakan Islam Indonesia telah mengenal pemikiran-pemikiran kenegaraan yang dikembangkan dari nilai-nilai Islam.

Selanjutnya, wacana Islam dan negara terus berkembang secara pesat di Indonesia hingga saat ini. Perkembangan ini tidak dapat dilepaskan dari diskursus yang berkembang di dunia Islam internasional terutama yang muncul di negara-negara di kawasan Timur Tengah dan Afrika, India dan Pakistan pada abad ke-18, 19 dan abad ke-20. Hal ini sangat tampak dari teori pemikiran-pemikiran dan gerakan-gerakan politik para tokoh abad ke-18, seperti Muhammad bin Abdul Wahab (1703-1782) di Jazirah Arabia, Syah Waliyullah (1702-1762) di India, Ahmad bin Idris (w 1837) dan Muhammad Ali bin al-Sanusi (1787-1859) di Afrika. Kemudian disusul pembaharu-pembaharu politik Islam di wilayah tersebut pada abad ke-19, seperti Rifa'ah alThahthawi (1801-1873), Jamaluddin al-Afghani (1838-1897), Sayyid Ahmad Khan (1817-1898) dan Muhammad Abduh (1849-1905).

Hingga abad ke-20, upaya dan pembahasan Islam dan negara dilakukan oleh Rasyid Ridha (1865-1935), Said al-Nursi (1867-1960), Muhammad Ali Jinnah (1876-1948), Mohammad Husayn Haikal (1888-1956), Ali Abdul Raziq (1888-1966), Thaha Husein (1889-1973), Ahmad Luthfi al-Syayyid (18721963), Abdul Hamid bin Bades (1890-1940), Abu Al-A'la al-Maududi (19031979), Sayyid Qutb (1906-1966), Hassan al-Banna (1906-1949), Fazlurrahman (1919-1988), Ali Shariati (1933-1977) dan sebagainya. ${ }^{2}$

bahwa umat Islam yang menjalankan ajaran Islam dengan baik adalah Pancasialis yang menjalankan Pancasila dengan baik pula. Lihat Harun Nasution, Islam Rasional; Gagasan dan Pemikiran, cet. V (Bandung: Mizan, 1998), h. 259.

2Tentang pemikiran para tokoh tersebut, secara reflektif dapat dilihat dalam John J. Donohue dan John. L. Esposito, Islam dan Pembaharuan, cet. V (Jakarta: Raja Grafindo Persada, 1995), h. 1-318. 
Bahkan jika menelusuri lebih jauh, akar-akar politik Islam dapat ditarik ke abad pertengahan yaitu dari zaman al-Mawardi (w.1058), al-Gazali (w.1111) hingga Ibnu Taymiyah (w. 1328) dan Ibnu Khaldun (w.1406). Dan terkahir dapat ditelusuri kepada periode lahirnya Piagam Madinah, periode Khulafa alRasyidin, hingga pada masa munculnya pertentangan antara kelompok Mu'awiyah dan Khawarij pada tahun pertama Hijriah sampai periode pemerintahan Umawiyah dan Abbasiah. ${ }^{3}$ Pemikiran para tokoh Islam klasik dan modern di atas cukup mempengaruhi dan mewarnai pemikiran politik Islam atau Islam politik khususnya terkait hubungan Islam dan negara di Indonesia selama abad ke-20 -mulai dari model konservatif, fundamental, modernis hingga sosialis-sekuler.

Di sisi lain, pemikiran-pemikiran dan praktik-praktik Islam politik di Indonesia tidak dapat dilepaskan dari upaya-upaya pengadaptasian pemikiran politik, hubungan "agama" dengan "negara" -mulai dari model liberalisme, sosialisme, sekularisme, marxisme hingga demokrasi- yang dihembuskan dari alam Barat (sejak masa Yunani) seperti Socrates (469-429 SM), Plato (429-347 SM), Aristoteles (384-322 SM), hingga Thomas Aquinas (1225-1274), Martin Luther (1438-1564), Niccolo Machiavelli (1469-1527), Thomas Hobbes (15881679), John Locke (1632-1704), Jean Jacque Reusseau (1712-1778) dan Karl Marx (1818-1883), Franklin Rosevelt (1882-1945), Vladimir Lenin (18701924), Joseph Stalin (1879-1953), Karl Kautsky (1854-1938) dan sebagainya. ${ }^{4}$

Paradigma politik dari Timur Tengah, India dan Pakistan yang mencerminkan dominasi "agama" di satu sisi, dan pemikiran politik dunia Barat, yang mencerminkan dominasi "negara", pada sisi yang lain, telah melahirkan beberapa aliran pemikiran politik Islam di sepanjang abad ke-20 yakni aliran dan faham konservatisme, fundamental, modernisme, sekularisme dan liberalisme, baik didasarkan pada warna "agama" maupun nation state.

Hal lain, yang menarik juga dicermati sebagai fenomena masyarakat Islam kontemporer bahwa hingga saat ini masih tampak bentuk-bentuk "kebingung-

\footnotetext{
${ }^{3}$ Lebih jelasnya dapat dilihat dalam; Șūfi Hasan Abū Țālib, Taṭīq al-Sharī’at al-Islāmiyyah fi I-Bilād al-'Arabiyyah (Kairo: al-Nahḍah, 1995), h. 74-78; John L. Esposito, Islam dan Politik (Jakarta: Bulan Bintang, 1990), h. 38-47.

${ }^{4}$ Pemikiran politik dari tokoh-tokoh Barat tersebut secara baik diulas oleh Deliar Noer dalam: Deliar Noer, Pemikiran Politik di Negeri Barat, cet. 1 (Bandung: Mizan, 1971).
} 
an" dari sebagian umat Islam dalam menyikapi persoalan relasi Islam dan negara. Model "kebingungan" ini sebetulnya tidak saja dialami oleh umat Islam Indonesia, akan tetapi juga dialami oleh seluruh negara-negara yang berpenduduk mayoritas Islam. Hal ini tercermin dari fenomena dunia Islam dalam melakukan manuver-manuver pemikiran politik dan aksi-aksi politik, sehingga identitas dan fungsi Islam dalam negara tidak pernah tegas dan jelas. Tulisan ini bermaksud untuk melakukan kajian ulang tentang relasi Islam dan negara, terutama dalam konteks isu-isu kontemporer sebagai muatan Islam maupun negara seperti demokrasi, civil society, HAM, gender, dan globalisasi.

\section{Rasionalitas Politik Islam dan Objektivitas Negara}

\section{Rasionalitas Politik Islam ${ }^{5}$}

Salah satu problematika yang dihadapi Islam adalah cibiran teori pedas yang pernah ditulis oleh Kuntowijoyo, bahwa agama (Islam) berdimensi banyak, sementara politik berdimensi tunggal yaitu dimensi rasional. Maka menjadikan agama sebagai politik adalah reduksi besar-besaran atas makna agama. Di sisi lain, urusan politik kenegaraan adalah perkara yang rasional, sementara agama adalah urusan kembali kepada wahyu. ${ }^{6}$ Menurut Kuntowijoyo, umat harus berada di garis depan dalam pembentukan politik Islam yang rasional, sebab bila tidak, umat Islam Indonesia mayoritas hanya akan menjadi penumpang dan bukan menjadi pengemudi, yang selama ini pengemudinya adalah negara atau non-Muslim.

Di antara dua entitas yaitu Islam (agama) dan negara, terdapat muatan "politik". Politik ini kemudian membentuk teori "politik Islam" dan "politik negara". Oleh karena itu, baik memisahkan maupun menyandingkan agama (Islam) dan negara bukan persoalan gampang. Dalam wacana politik, dua entitas tersebut selalu berada dalam ketegangan dan senantiasa terjadi perdebatan yang cukup panjang. Oleh karena itu, sebuah tawaran pemahaman

5Penggunaan term "Politik Islam" dimaksudkan untuk sebuah paradigma yang memandang perlunya komunitas Islam yang berfungsi secara maksimal sehingga tercipta masyarakat Islam, dan "politik Islam" tidak dimaksudkan untuk sampai pada pemikiran dan dan gagasan yang bertujuan mendirikan "negara Islam" atau "negara agama", atau lebih tepatnya "Islam Ideologis".

6Kuntowijoyo, "Agama Berdimensi Banyak, Politik Berdimensi Tunggal", dalam Abu Zahrah (ed.), Politik Demi Tuhan (Bandung; Pustaka Hidayah, 1999), h. 121-125. 
yang lebih longgar, mengakar dan rasional ${ }^{7}$ dalam menyikapi masalahmasalah dunia dan agama, atau Islam dan negara, telah disampaikan alShahrastanī seorang ahli kalam:

$$
\text { يتناهى ...... والنصوص إذا كانت متنا هية و الو قائع غير متنا هية وما لا يتناهى لا يضبطه ما }
$$

“.... bahwa nas atau teks (al-Qur'an dan al-Hadis) sudah berakhir, sedangkan peristiwa-peristiwa (realita kehidupan) baru yang memerlukan penyelesaian senantiasa terjadi (berkembang), dan sesuatu yang tiada berakhir tidak dapat diatur oleh sesuatu yang sudah berakhir...."

Pandangan al-Shahrastanī di atas kemudian melahirkan kaidah yang mendasar yakni bahwa "wahyu sudah berakhir diturunkan, sedangkan peristiwaperistiwa baru yang memerlukan penyelesaian dan solusi tidak pernah berakhir". Kaidah ini dapat disebut sebagai teori yang relevan sehingga menjadi keniscayaan untuk dijadikan pijakan guna melakukan dan mengembangkan ijtihad atau pemikiran-pemikiran baru.

Pandangan lain yang layak dijadikan pertimbangan untuk meyakinkan umat Islam mengenai rasionalitas Islam adalah uraian Issa Boullata, yang mengutip dari pemikiran Hasan Sya'b, seorang sarjana Libanon, bahwa "ijtihad terkait dengan semangat Islam dan adaptasinya dengan kondisi dan kebutuhan manusia yang senantiasa berubah, dan itu dimulai dari "dinamisme kreatif Tuhan dalam al-Qur'an".9 Sya'b menyajikan Islam sebagai sistem keyakinan yang memiliki dinamisme permanen melalui al-Qur'an dan kreativitas intelek-

\footnotetext{
${ }^{7}$ Rasionalitas Islam secara normatif dikenal, melalui konsep-konsep al-Qur'an dan Hadis. AlQur'an melalui term "Iqra'" merupakan perintah Allah kepada manusia untuk membaca, dan merupakan wahyu pertama yang diturunkan Allah kepada Nabi Muhammad. Sedangkan melalui hadis, yakni dua sabda nabi Muhammad, pertama, "Tiada agama bagi yang tidak mempunyai (menggunakan) rasio, akal dan nalar" (HR. Bukhari) dan Hadis mengenai kisah pengutusan Mu'adh bin Jabal ke Yaman, yakni ketika Nabi memberikan keleluasaan mengembangkan pola ijtihad atau mengunakan nalar seluas-luasnya terhadap persoalan-persoalan yang tidak ditemukan dalam alQur'an maupun Hadis. Pada akhirnya semakin meyakinkan dalam tataran operasionalnya ketika menemukan ungkapan populer al-Shahrastanī, sebagaimana akan dikemukakan selanjutnya.

${ }^{8} \mathrm{Abū}$ al-Fath Muhammad 'Abd al-Karīm ibn Abī Bakr Ahmad al-Shahrastanī, al-Milal wa al-Nịhal (Kairo: Bāb al-Halabī, 1967), h. 199.

9 Issa J. Boullata, Dekonstruksi Tradisi, Gelegar Pemikiran Arab Modern, cet. I (Yogyakarta: LKIS, 2001),h. 101.
}

24 || Volume 25, Nomor 1, April 2015

AL-AHKAM - ISSN 0854-4603 
tual melalui ijtihad. Sya'ab juga menggambarkan manusia sebagai instrumen Tuhan di bumi untuk melanjutkan dinamisme, kreativitas dalam kebebasan, kecintaan dan keadilan.10

Dari dua proposisi di atas setidaknya dapat dirumuskan bahwa mengenai rasionalitas Islam tidak lagi perlu dipersoalkan, karena Islam memang agama rasional. Persoalannya adalah implementasi rasionalitas Islam itu sendiri dalam menyikapi isu-isu kontemporer sepanjang zaman, terutama bagi kehidupan penganut Islam baik sebagai individu maupun sebagai kelompok masyarakat mikro dan makro.

Oleh karena itu, memahami rasionalitas Islam, termasuk dalam soal politik Islam, masih terus perlu mendapatkan terjemahan-terjemahan pembaruan agar tidak hanya terlena dengan konsep-konsep "normatif'-nya saja yang justru hanya akan membuat sikap statis, berjalan di tempat, tanpa melakukan perubahan-perubahan yang lebih realistis dan urgen dalam membangun kualitas kerja, yakni Sumber Daya Manusia (SDM) umat Islam. SDM yang dimiliki umat Islam sangat tidak sebanding, bahkan sangat jauh prosentasenya jika dibandingkan dengan penderitaan dan problematika yang harus diselesaikan, baik sebagai agama yang under development maupun sebagai agama yang mencari "identitas"-nya dalam sebuah negara. Inilah fokus kesenjangan yang terjadi dalam tubuh umat Islam, terlebih lagi jika dikaitkan dengan politik Islam, baik dalam tataran teoritis maupun praktis. Sebab manakala umat Islam sedang membangun diri, dalam waktu yang sama juga berusaha mencari identitasnya yang dipandang sesuai dengan nilai-nilai universalitas Islam.

Di Indonesia, soal rasionalitas Islam, telah diyakini sebagai way of life oleh para tokoh dan cendekiawan, mulai tokoh-tokoh dan cendekiawan pra kemerdekaan hingga masa awal pasca kemerdekaan seperti H. Samanhoedi, H.O.S. Cokrominoto, Agus Salim, Abdul Moeis, Mohammad Hatta, Kahar Muzakkir, Hamka, A. Hassan, Wahid Hasyim, Syafruddin Prawiranegara, Mohammad Roem, M. Natsir, H.M. Rasyidi, Harun Nasution dan sebagainya. Melalui karya-karya, gerakan dan cara pandang, masing-masing telah me-

10Ibid, h. 104. 
nampilkan rasionalisasi Islam dalam kehidupan sosial-kemasyarakatan, keberagamaan, kebangsaan maupun kenegaraan.

Perjalanan panjang itu, kemudian menghasilkan suatu fakta bahwa ternyata fungsi hukum waḍ'i (buatan manusia), yang lebih dikenal dengan hukum positif di satu sisi, dan fungsi hukum samawī (ajaran Tuhan), pada sisi yang lain, belum dapat dibumikan secara maksimal dalam sebuah komunitas semacam negara. Cara kerja rasionalits Islam pun masih senantiasa dipertanyakan dalam berinteraksi dengan negara di mana mereka hidup, padahal umat Islam telah melahirkan suatu disiplin yang dikenal dengan fiqh al-siyāsī (fikih politik), yang pada gilirannya melahirkan fatwa-fatwa politik.

Mengenai fikih politik yang memiliki cakupan begitu luas dalam khazanah Islam, oleh A. Djazuli disederhanakan menjadi tiga bagian, yaitu: Pertama, fikih politik yang membahas bagaimana hubungan pemimpin dengan rakyat, yang lazim disebut sebagai dustūriyyah. Termasuk dalam kategori ini misalnya mengenai hubungan negara dengan agama, hukum mengangkat pemimpin, pemilihan pemimpin dan bay'at (pengambilan sumpah). Kedua, fikih politik yang membahas mengenai hubungan antar negara atau dawliyyah, misalnya mengenai pola hubungan antara negara, termasuk hubungan dengan negaranegara non-Muslim. Ketiga, fikih politik yang membahas tentang harta atau māliyyah. ${ }^{11}$ Abdul Wahab Khallaf menjelaskan cakupan fikih siyāsah māliyah menjadi: 1) politik keuangan; 2) pajak atau kharaj; 3) pendayagunaan keuangan; 4) pemungutan keuangan dan penggunaannya, serta kas negara (bayt al-māl). ${ }^{12}$ Upaya kerja-kerja rasionalitas fikih politik tersebut, seharusnya mampu memberikan solusi-solusi politik, baik politik dalam negeri maupun luar negeri.

Selama 14 abad, umat Islam telah menampilkan ragam pemikiran dalam merespons persoalan-persoalan baru. Ragam respons umat Islam dengan konsepnya yang asasi yaitu al-Qur'an dan Hadis menyisakan petanyaanpertanyaan yang sangat serius di masa sekarang terkait dengan kondisi umat Islam selama 10 abad terakhir, yang tidak kunjung menampilkan perubahan

\footnotetext{
11A. Djazuli, Fiqh Siyasah; Implementasi Maslahat Umat dalam Rambu-rambu Syari'ah (Bandung: Gunung Djati Press, 2000), h. 3.

${ }^{12}$ Abdul Wahab Khallaf, Politik Hukum Islam, terj. Zainuddin Adnan (Yogyakarta: Tiara Wacana, 1994), h. 79-119.
} 
fundamental dalam membangun peradaban baru. Di antara pertanyaan yang dimaksud adalah pertanyaan yang telah sangat popular di kalangan umat Islam yaitu mengapa bangsa-bangsa Islam mundur di tengah-tengah kemajuan bangsa-bangsa non Islam? Terinspirasi pertanyaan ini, Ali Nadwi (1914-1999) membuat pertanyaan yang kontras, dan mengabadikannya dalam buku $M \bar{a} d h \bar{a}$ Khasira al-ĀAlam bi Inhițāț al-Muslimīn (apa derita dunia, akibat kemunduran umat Islam)?

Pertanyaan di atas telah berusaha dijawab oleh berbagai kalangan, namun dalam kenyataannya hingga saat ini, dunia Islam masih harus menerima kenyataan bahwa umat Islam di dalam komunitas dunia internasional masih sangat jauh tertinggal, bahkan terpinggirkan dibanding kemajuan yang dicapai oleh dunia non Islam seperti negara-negara Eropa, Amerika, Rusia, Korea Selatan, China, Jepang dan Australia, baik di bidang sains; informasi, komunikasi dan teknologi, maupun di bidang politik dan ekonomi.

Terkait dengan proposisi di atas, maka Indonesia sebagai negara dan sebagai bangsa yang berpenduduk mayoritas Islam, berusaha memberikan respons terhadap pertanyaan yang problematik tersebut. Respons umat Islam Indonesia dalam membangun dan memajukan bangsanya hingga kini telah menghasilkan upaya-upaya pembaruan di berbagai bidang kehidupan bermasyarakat, berbangsa, dan bernegara, yang secara historis dapat dibagi menjadi empat periode yaitu; Pra Kemerdekaan, Pasca Kemerdekaan, Orde Baru dan Pasca Orde Baru, dan Era Reformasi. ${ }^{13}$

\section{Objektivitas Negara terhadap Agama}

Negara, sebagaimana dirumuskan dalam kamus bahasa Indonesia memiliki dua pengertian. Pertama, organisasi di suatu wilayah yang mempunyai kekuasaan tertinggi yang sah dan ditaati oleh rakyat; Kedua, kelompok sosial yang menduduki wilayah atau daerah tertentu yang diorganisir di bawah lembaga politik dan pemerintah yang efektif, mempunyai kesatuan politik,

\footnotetext{
${ }^{13}$ Diskursus sejarah politik Islam Indonesia dibahas oleh Bahtiar Effendy, dalam bukunya Islam dan Negara terbit 1998, yang sebelumnya telah terbit karya lainnya yang ditulis bersama Fachry Ali, dalam Merambah Jalan Baru Islam, terbit tahun 1986 dan Re-politisasi Islam; Pernahkah Islam berpolitik? terbit tahun 2000, serta Teologi Baru Politik Islam terbit 2001.
} 
berdaulat sehingga berhak menentukan tujuan nasionalnya. ${ }^{14}$ Dengan demikian negara dalam pengertian modern adalah negara yang memiliki unsurunsur: wilayah, kekuasaan dan rakyat serta kedaulatan.

Berdasarkan pengertian di atas, maka Indonesia sebagai sebuah negara adalah ciptaan masyarakat Indonesia sendiri, yang karenanya negara dalam posisi objek menjalankan fungsinya sesuai dengan aturan-aturan yang ditetapkan pada tubuh negara. Disinilah objektivitas negara menjalankan cita-citanya dalam berbagai aspek kehidupan penciptanya yaitu kepentingan-kepentingan warganya mulai dari politik, ekonomi, pendidikan, budaya dan agama.

Nilai-nilai ajaran agama (termasuk Islam) dipandang oleh banyak kalangan secara representatif telah termuat di sebagian besar dari keseluruhan undangundang dan peraturan negara, secara normatif maupun secara yuridis formal ${ }^{15}$ sesuai dengan amanat rakyat. Mulai dari UUD 1945,16 pengesahan UndangUndang Pendidikan Nasional (UUPN) tahun 1988, hingga pada legalitas lembaga-lembaga Islam seperti Peradilan Agama (Islam) melalui pengesahan Undang-Undang Peradilan Agama (UUPA) 1989,17 Majelis Ulama Indonesia (MUI) ${ }^{18}$ dan Kompilasi Hukum Islam (KHI) ${ }^{19}$ di Indonesia tahun 1991.

\footnotetext{
${ }^{14}$ Kamus Besar Bahasa Indonesia, h. 685.

15Muhammad Daud Ali membagi pemberlakuan hukum Islam di Indonesia menjadi dua yaitu secara normatif dan yuridis, lihat Muhammad Daud Ali, Hukum Islam, cet. XII (Jakarta: Raja Grafindo, 2004),h. 6.

16Menganalisis Undang-Undang Dasar 1945, hingga setelah mengalami amandemen selama empat kali selama era reformasi masing-masing tahun 1999, 2000, 2001, dan 2004, tampak keseluruhan isinya sesuai dengan pesan-pesan Islam, dan tidak ditemukan pertentangan yang fatal. Lihat: UUD'45 dan Amandemennya di bawah Kabinet Indonesia Bersatu, terbitan Fokus Media.

${ }_{17}$ Tentang teori dan praktek Peradilan Agama dapat dilihat dalam; Bustanul Arifin, Pelembagaan Hukum Islam di Indonesia (Jakarta: Gema Insani Press, 1996); Cik Hasan Bisri, Peradilan Agama di Indonesia (Jakarta: Raja Grafindo Persada, 1996); Amrullah Ahmad, dkk, Dimensi Hukum Islam dalam Sistem Hukum Nasional (Jakarta: Gema Insani Press, 1996); Jaih Mubarak (Editor), Peradilan Agama di Indonesia (Bandung: Pustaka Bani Quraisy, 2004).

${ }^{18}$ Himpunan fatwa MUI sebagai lembaga legal negara tidak saja memuat fatwa-fatwa hukum agama tetapi juga fatwa-fatwa politik dalam berbagai dimensi sosial kemasyarakatan, ilmu pengetahuan dan teknologi, dan sebagainya. Baca: Himpunan Fatwa Majelis Ulama Indonesia, 2003.

${ }^{19}$ Kompilasi Hukum Islam adalah kumpulan produk hukum Islam Indonseia yang diracik pada masa 'Orde Baru', sehingga disebut sebagai "Fikih Mazhab Negara" atau "Fikih Mazhab Orde Baru". Marzuki dan Rumadi megistilahkan dengan "fikih Islam berwawasan Pancasila". Isi KHI meliputi tiga buku (Pembahasan) yaitu; buku tentang Hukum Perkawinan terdiri dari 19 Bab dan 170 Pasal, buku kedua tentang Hukum Kewarisan terdiri dari 6 Bab dan 44 Pasal, serta buku mengenai Hukum
} 
Bahkan dalam perkembangan yang sangat monumental, sejak era reformasi, tahun 1998, kebebasan "berekspresi" semakin terbuka luas hingga pada pendirian sejumlah partai-partai yang berbasis Islam, yang secara historis dapat dirunut hingga pada masa pendirian partai politik Sarekat Islam (SI) pada 11 November 1912.

Dengan demikian kedudukan agama (Islam) dalam konstelasi negara, jika ditinjau dari perspektif politik, negara telah merespons keberadaan agama di negara Republik Indonesia, ini di satu sisi. Pada sisi yang lain, posisi agama, khususnya Islam telah menawarkan partisipasinya secara konseptual di bawah sebuah negara yang berdasarkan Pancasila.

\section{Realitas “Negara Modern" dan “Islam Modern"}

Negara bangsa (nation state) merupakan kenyataan sejarah yang tidak dapat dihindari oleh bangsa manapun, termasuk bangsa Indonesia. Selain karena tuntutan global, negara-bangsa merupakan konsep negara modern yang menjanjikan penyelesaian bagi setiap bangsa dalam menghadapi kenyataan-kenyataan pluralisme, toleransi, dan demokrasi.

Maka dari itu, memahami dengan baik fenomena negara modern adalah suatu keniscayaan bagi setiap akademisi, pemikir maupun praktisi Negara, karena sejak lahirnya konsep Negara-bangsa atau nation state pada abad ke-19, dunia Islam kembali menghadapi persoalan baru yang tidak pernah terbayangkan sebelumnya. Sejak awal abad ke-20, ketika mulai timbul berbagai gerakan kebangsaan dalam situasi kolonial, pusat perhatian gerakan Islam lebih banyak tertuju pada soal-soal kemasyarakatan, khususnya pendidikan, perbaikan sosial ekonomi dan dakwah, dalam rangka menyiarkan agama Islam, sesuai dengan aliran keagamaan masing-masing organisasi pergerakan. ${ }^{20}$

Negara dalam pengertian nation state adalah ide modernitas terpenting. Para tokoh pergerakan dan cendekiawan Indonesia telah berusaha berpikir dalam kerangka konsep negara modern ini. Menururt Dawam Rahardjo,

Perwakafan. Secara baik dirangkum oleh Wasit Aulawi, "Kompilasi Hukum Islam dalam Sistem Hukum Nasional” , Pidato Pengukuhan, IAIN Jakarta, 1989.

20Dawam Raharjo, "Agama Masyarakat dan Negara," dalam Mukti Ali, dkk, Agama dalam Pergumulan Masyarakat Kontemporer (Jakarta: Tiara Wacana, 1998), h. 131. 
bahwa dalam konteks tersebut, terdapat tiga macam konsep negara. Pertama, negara dipandang sebagai seperangkat kelembagaan yang terdiri dari lembaga eksekutif, legislatif, dan administrasi di pusat maupun di daerah, peradilan polisi dan tentara. Kedua, konsep negara secara struktural, yang pengertiannya digambarkan Marx bahwa negara tidak lain adalah wadah bagi eksekutif yang melaksanakan kepentingan kelas. Ketiga, memandang negara sebagai penumbuhan ide yang ideal dalam masyarakat. Model ini memandang negara sebagai kekuatan yang independen dan berdiri di atas semua golongan dan mengatasi seluruh kepentingan masyarakat.21

Lalu bagaimana dengan konsep negara modern menurut Islam? Selama 14 abad Islam masih dirasakan langka bahkan belum pernah menawarkan konsep kenegaraan modern dan implementasinya, karena selama itu umat Islam tidak menemukan konsep model nation state, melainkan yang ditemukan adalah model-model kepemimpinan kekhilafahan yang berbentuk monarkhis dalam format khiläfah, amīr, șulțān, dan al-mamlakah. Sampai saat ini belum juga ditemukan bahkan mungkin tidak akan ditemukan pola bernegara yang paling ideal untuk orang Islam, karena memang Islam terlalu besar untuk dihadapkan dengan negara. Oleh karena itu, pengalaman panjang sejarah Islam dalam bersentuhan dengan lembaga kekuasaan, dengan berbagai model dan bentuk kekuasaan yang telah terterapkan di wilayah komunitas masyarakat Islam, hendaknya menjadi modal besar dalam memahami realitas negara modern yang berkembang hingga saat ini.

Negara, sebagaimana dikemukakan Mac Iver dalam bukunya The Modern State, seperti dikutip Rumadi, menyatakan bahwa pada dasarnya, ide pembentukan negara adalah untuk memenuhi kebutuhan hidup masyarakat guna mewujudkan kehidupan masyarakat yang bahagia. ${ }^{22}$ Dengan demikian diharapkan terlahir walfare state, yaitu negara yang dapat membahagiakan kehidupan rakyatnya. John L. Esposito menjelaskan bahwa pola pembangunan negara modern dalam dunia politik Islam menampilkan tiga orientasi umum yaitu negara sekuler, negara berasaskan Islam, dan negara Muslim. ${ }^{23}$ Turki

\footnotetext{
21 Ibid, h. 137-139.

${ }^{22}$ Rumadi, “Agama dan Negara; Dilema Regulasi Kehidupan Beragama di Indonesia”, dalam Istiqra', Jurnal Penelitian Ditpertais, Volume 04, Nomor 01, 2005, h. 119.

23John L. Esposito, Islam dan Politik, h. 132-133.
} 
telah memilih jalan sekuler secara total. Sementara Saudi Arabia dan Pakistan secara resmi mengumumkan ciri Islam bagi negaranya, baik untuk politik dalam negerinya maupun untuk kepentingan politik luar negeri. Negaranegara seperti Tunisia, Aljazair, Mesir, Suriah, Iran dan Jordan, berusaha merefleksikan penerapan syariat sebagai sumber hukum dan mengumumkan Islam sebagai agama resmi negara. ${ }^{24}$ Adapun praktik-praktik yang dianut oleh beberapa negara berpenduduk mayoritas Islam tersebut, nampaknya menggambarkan realitas simbolis formalistik Islam dalam menjalankan negara. Bahkan sangat terkesan simbolis formalistik hanya digunakan sebagai sarana perebutan kekuasaan, yang pada praktiknya tampak antagonis. ${ }^{25}$

Dalam konteks negara modern, Indonesia dengan Pancasila-nya merupakan rumusan negara modern dalam "rumusan ideal", seperti termaktub dalam Mukaddimah UUD 1945. Upaya pendekatan agama sampai pada tingkat formal "Negara Islam Indonesia" tampak gagal karena dipandang bertentangan dengan cita-cita negara modern. Karena itu, salah satu dari beberapa poin penting dikemukakan Bahtiar Effendy, bahwa gagasan tentang negara-bangsa bertentangan dengan konsep ummah, yaitu masyarakat Islam yang tidak mengenal batas-batas politik maupun daerah. ${ }^{26}$ Gagasan model pemikiran ini menurut Bahtiar Effendy banyak dipraktikkan oleh negara-negara yang memposisikan sistem dan dasar-dasar politiknya sebagai yang berlawanan dengan ajaranajaran Islam. Terkait dengan negara modern dan modernisasi Islam, M. Syafi'i Anwar menemukakan bahwa bagi kalangan Islam, modernisasi merupakan persoalan yang relatif baru, yang oleh karenanya wajar apabila muncul reaksi dan respons yang berbeda dari berbagai kelompok Islam. ${ }^{27}$

Beberapa pandangan di atas menyiratkan kepada kita bahwa dalam negara-negara modern, belum tentu berisi agama-agama modern, dalam hal ini Indonesia modern dan Islam modern. Masing-masing masih harus melaku-

\footnotetext{
${ }^{24}$ Ibid.

25Dalam konteks Indonesia modern dan Islam, Bahtiar Effendy telah menjelaskan dan mengkritisinya dengan menggunakan dasar-dasar teori Politik Islam yang berkembang hingga hubungan Islam dan negara yang tidak serasi dalam pembahasan "Menuju Hubungan Politik Islam yang Integratif antara Islam dan Negara" Lihat: Bahtiar Effendy, Islam dan Negara: Transformasi Gagasan dan Praktik Politik Islam di Indonesia (Jakarta: Paramadina, 1998), h. 59-338.
}

26Ibid, h. 12.

27M. Syafi'i Anwar, Pemikiran dan Aksi Islam Indonesia (Jakarta: Paramadina, 1995), h. 327-328. 
kan pembaruan-pembaruan yang lebih aktual dan dinamik untuk menemukan jati diri kemoderenan masing-masing tanpa harus mengorbankan salah satu dari "negara" atau "agama".

\section{Relasi Fungsional Islam dan Negara}

Pemikiran politik yang ditawarkan Islam sejak masa awal Islam sampai abad ke-20 keseluruhannya adalah berusaha memberikan pemaknaan terhadap kekuasaan secara normatif, yaitu bagaimana membentuk pemerintahan atau kepemimpinan dan lembaga kekuasaan (negara) yang ideal dan bermoral. Persoalannya adalah hingga kini, agama dan negara merupakan dua hal yang tidak mudah disatukan maupun dipisahkan.

Muhammad Imarah, seorang sarjana berkebangsaan Mesir yang dikenal sangat kritis dalam diskursus mengenai Islam politik atau politik Islam, berpendapat bahwa pemisahan negara dari agama tidak mungkin diaplikasikan karena agama tidak pernah direalisasikan dalam ruang hampa, tetapi dalam pemikiran dan perilaku manusia di mana mereka hidup. Bahwa Islam membedakan kedua terma tersebut memang benar, namun tidak untuk memisahkannya. ${ }^{28}$ Menurut Imarah, suatu kesalahan intelektual bila tidak memasukkan agama sebagai salah satu faktor yang mempengaruhi masyarakat. Di sisi lain, memberikan karakter religius pada politik dan sistem pemerintahan dianggap sesuatu yang bertentangan dengan semangat Islam. Karena itu menurutnya, Islam membedakan antara komunitas agama dan komunitas politik. ${ }^{29}$ Komunitas agama dilaksanakan oleh Muslim beriman dan komunitas politik dilaksanakan oleh mayarakat dari beragam keimanan. Imarah melihat pembedaan yang dilakukan Islam antara agama di satu sisi dengan politik dan persoalan-persoalan keduniaan di sisi lain. Di sinilah antara agama dan politik bukan merupakan al-fașl atau "pemisahan", tetapi lebih pada al-tamyīz atau "pembedaan" yang berdampingan.

Pemikiran Imarah di atas, besar kemungkinan didasarkan pada pandangannya yang lain, sebagaimana dikutip Bahtiar Effendy, bahwa Islam sebagai

\footnotetext{
28Muḥammad Imārah, al-Islām wa al-Sulțah al-Dīniyyah, cet. II (Beirut: Mu'assasat al-'Arabiyyah wa al-Nashr, 1980), h. 103.

29lbid.
} 
agama tidak menentukan sistem pemerintahan tertentu bagi kaum Muslim..$^{30}$ Imarah berargumen bahwa soal-soal yang akan berubah oleh kekuatan evolusi harus diserahkan kepada akal manusia, dibentuk menurut kepentingan umum dan dalam rangka prinsip-prinsip umum yang digariskan agama. ${ }^{31}$

Tipologi pemikiran Imarah tersebut menggambarkan sebuah harapan sekaligus tantangan bagi umat (negara) Islam dalam menyikapi jejak-jejak politik Islam di dunia internasional, termasuk di Indonesia. Sebuah pandangan yang lahir di abad ke-15 sejak kelahiran Islam, ketika telah berhadapan dengan sistem negara modern yaitu nation-state, yang menginginkan adanya benang merah yang dapat merumuskan relasi Islam dan negara.

Di Indonesia sendiri, hubungan agama dengan negara telah banyak ditulis dan dijelaskan oleh para pakar melalui sejumlah kajian dan penelitian, utamanya pada tiga dekade terakhir, sejak tahun 70-an hingga 90-an. Diantara mereka adalah Nurcholis Madjid, Dawam Raharjdo, Ahmad Wahib, Djohan Effendy, Din Syamsuddin, Bahtiar Effendy,32 Fakhri Ali, M. Syafi'i Anwar, Marzuki Wahid, Rumadi, dan sebagainya.

Dengan demikian, dapat difahami bahwa hubungan Islam dan negara adalah hubungan fungsional, yaitu bagaimana agar Islam dapat menjalankan fungsinya dalam wilayah dan komunitas sebuah negara di satu sisi, dan demikian pula, bagaimana agar negara dapat menjalankan fungsinya sebagai badan organisasi yang warga dan wilayahnya adalah komunitas mayoritas penganut Islam, di sisi yang lain. Negara Indonesia secara normatif dan yuridis telah mengakomodasi prinsip-prinsip keagamaan yang kuat, termaktub dalam undang-undang dan peraturan-peraturan pemerintah. Sejarah Islam Indonesia juga menunjukkan bahwa sejak awal kelahiran Indonesia sampai pada era reformasi ini, pemikiran dan cita-cita integral antara negara dan agama masih dominan, dibandingkan dengan pandangan sekularistik, seperti yang berlaku di Turki. Sudahkah terjadi relasi fungsional antara agama dan negara di Indonesia?

\footnotetext{
30Bahtiar Effendy, Islam dan Negara ..., h. 13.

31 Muḥammad Imārah, al-Islām wa al-Sulțah al-Dīniyyah, h. 101-103 dan 114.

32Bahtiar Effendi misalnya, seorang ahli politik Islam modern-kontemporer. Dalam beberapa pertemuan dengan mahasiswa pascasarjana program Doktor di UIN Syarif Hidayatullah, antara bulan Oktober 2006 hingga Januari 2007 berulang kali menekankan sebuah proposisi penting, bahwa dalam soal hubungan Islam dan negara yang diutamakan adalah bagaimana agar agama (Islam) maupun negara masing-masing dapat berfungsi secara baik.
} 
Diskursus relasi fungsional antara Islam dan negara diklasifikan ke dalam beberapa bentuk. Pertama, unified paradigm (paradigma integralistik), yaitu bahwa agama dan negara merupakan satu kesatuan yang intergrated, dan politik atas nama negara merupakan bagian dari agama, dan negara merupakan lembaga politik dan lembaga agama sekaligus. ${ }^{33}$ Pandangan ini kemudian melahirkan teori bahwa Islam adalah dīn wa dawlah (Islam adalah agama [dan sekaligus] negara). Pada gilirannya kemudian, tercetuslah istilah "negara agama" atau "negara Islam. Berdasarkan konsep ini dapat ditarik beberapa pengertian dilematis, antara lain adalah: 1) kehidupan negara dapat diatur oleh agama; 2) kepala negara adalah pemegang kekuasaan agama kekuasaan politik; 3) bahwa taat kepada negara, berarti taat kepada agama; 4) melawan negara berarti melawan agama (Tuhan), dan 5) negara sebagai lembaga politik sekaligus sebagai lembaga agama.

Beberapa pemikir kontemporer Indonesia seperti Rumadi, Marzuki dan Jaih Mubarak, mengutip dari pendahulu-pendahulunya, memandang model ini sebagai warisan pola pemikiran Islam tradisional dan fundamentalis, di era negara-negara modern dan kontemporer. Kalangan tradisional seperti Rasyid Ridha (1865-1935), sedangkan kalangan fundamentalis seperti Khursyid Ahmad, Muhammad Asad, Muhammad Husayn Fadlullah, Sayyid Qutb, Abu alA'la al-Maududi dan Hasan Turabi. ${ }^{34}$

Paradigma ini banyak berpengaruh pada pemikir-pemikir Islam Indonesia. Di antaranya adalah M. Natrsir, Kasman Singodimedjo, Zaenal Abidin, Isa Anshari dan K.H. Masykur. Mohammad Natsir misalnya, mewariskan pemikiran mengenai hubungan negara dengan Islam yang dinilai oleh beberapa cendikiawan Islam lainnya sebagai pemikiran dalam wajah ganda. Di satu sisi menerima Pancasila, dan pada sisi yang lain menolak Pancasila. Natsir pernah berpidato yang isinya: "Dan saya katakana, Indonesia juga adalah negara Islam, oleh kenyataan, Islam diakui sebagai agama dan anutan jiwa Indonesia, meskipun tidak disebutkan dalam konstitusi, Islam itu adalah agama negara". 35

\footnotetext{
33Jaih Mubarak, Fiqh Siyasah (Bandung: Pustaka Bani Quraisy, 2005), h. 57.

${ }^{34}$ Marzuki Wahid dan Abd Maqsith Ghazali, "Relasi Agama dan Negara", dalam Istiqra', Jurnal Penelitian Ditpertais, Volume 04, Nomor 01, 2005, h. 150-153.

35Mohammad Natsir, Islam sebagai Dasar Negara Uakarta: Dewan Da'wah Islamiyah Indonesia, 2000), h. 17-18.
} 
Mohammad Natsir juga memberikan pengertian persatuan agama dan negara dalam sebuah uraiannya:

"Bagi kita kaum Muslimin, negara bukanlah suatu badan yang tersendiri yang menjadi tujuan. Dan dengan "persatuan Agama dengan Negara" kita maksudkan, bukanlah bahwa 'agama' itu cukup sekedar dimasuk-masukkan saja di sana sini kepada 'negara' itu. Bukan begitu. Negara, bagi kita, bukan tujuan, tetapi alat. Urusan kenegaraan pada pokoknya dan pada dasarnya adalah satu bagian yang tak dapat dipisahkan, satu "itergreerend deel" dari Islam. Yang menjadi tujuan ialah; kesempurnaan berlakunya undang-undang ilahi, baik yang berkenaan dengan kehidupan manusia sendiri, sebagai individu, ataupun sebagai anggota dari masyarakat"36

Menurut Dawam Rahardjo, paradigma integralistik adalah paradigma yang dikembangkan oleh tokoh nasionalis seperti Supomo dan Bung Hatta melalui jargon "negara integralistik" dalam sidang Badan Penyelidikan Usaha-Usaha Persiapan Kemerdekaan Indonesia (BPUPKI). Meskipun konsep integralistik ini berasal dari Adam Muller, Hegel dan Spinoza, Supomo dan Hatta berusaha memberikan kontribusi pemikiran tentang kedudukan agama, khususnya Islam dalam negara. Bagi Supomo, negara integralistik tidak berarti a-religius, sementara bagi Hatta, agama dan ide-ide keagamaan mempunyai peluang untuk mempengaruhi negara, tetapi hal itu bisa dilakukan dalam proses demokratis, sepanjang idenya tidak menyangkut konsep negara berdasarkan suatu agama. ${ }^{37}$

Kasus Indonesia, secara historis, konteks kesatuan agama dan negara telah menampilkan berbagai corak ketegangan dan kecemasan di satu sisi, dan corak kemesraan dan phobia pada sisi yang lain. Ketegangan kuat terjadi pada periode kepemimpinan Soekarno. Hal ini dapat dipahami karena bangsa Indonesia masih tergolong baru dalam mewacanakan hubungan fungsional antara negara dan agama. Di era reformasi, ditandai dengan lahirnya partaipartai yang menegaskan dirinya sebagai partai Islam. Fenomena ini menggambarkan dua wajah sekaligus yaitu wajah kemesraan dan sekaligus wajah ketegangan. Wajah kemesraan negara dengan agama (terutama Islam), karena terbukanya secara bebas mendirikan partai-partai politik tanpa membatasi

\footnotetext{
36Mohammad Natsir, Capita Selecta (Jakarta: Bulan Bintang, 1973), h. 432.

${ }^{37}$ Baik Hatta maupun Supomo, keduanya menganut paham sekulerisme, tapi keduanya mengakui pengaruh agama terhadap negara. Lihat: Dawam Raharjo, "Agama Masyarakat dan Negara”, h. 138139.
} 
sama sekali performanya agama atau bukan. Sementara wajah ketegangan tampak dari partai-partai itu sendiri, yang pada gilirannya negara akan melibatkan diri dalam ketegangan di antara para partai yang berselisih atau perpecahan internal partai. Misalnya saja perpecahan beberapa partai Islam yang menginginkan solusi dari negara melalui keputusan Mahkamah Konstitusi. Singkatnya, eksistensi Islam dalam persentuhannya dengan wilayah politik, terkadang mencerahkan sejarah dan peradaban, atau sebaliknya terkadang menggelapkannya. Adakalanya Islam menjadi kekuatan positif, adakalanya tampil menjadi kekuatan negative. Faktanya Islam bisa menjadi energi untuk humanisasi dan dehumanisasi.

Kedua, symbiotic paradigm (paradigma simbiotik); Bahwa agama dan negara berhubungan secara simbiotik yaitu hubungan saling menguntungkan dan bersifat timbal balik. Artinya, agama memerlukan negara, begitu pula negara memerlukan agama. Agama membutuhkan negara karena negara dapat dijadikan media untuk mengembangkan agama, sementara negara memerlukan agama karena negara dapat berkembang atas bimbingan dan etika moral agama.

Dalam konteks di atas, adalah menarik apa yang dikemukakan Bahtiar Effendy, mengutip pendapat Michael Hudson bahwa "Sebenarnya pertanyaan yang patut dikemukakan bukanlah yang kaku dan salah arah karena bergaya mendikotomisasi, yakni apakah Islam dan pembangunan politik itu bertentangan atau tidak, melainkan seberapa banyak dan pemikiran Islam yang bagaimana yang sesuai dengan politik modern". Bahtiar Effendy kemudian mengomentari pandangan tersebut dengan mengajukan pertanyaan serupa dalam konteks Indonesia yakni; jenis Islam manakah (dalam pengertian interpretatif), atau pemikiran-pemikiran dan praktik politik Islam yang manakah yang dapat menjamin terbinanya hubungan yang baik antara Islam dengan negara-bangsa di Indonesia? ${ }^{38}$

Hubungan simbiosis ini dapat mencerminkan setidaknya tiga bentuk hubungan yang kemungkinan akan terjadi yakni; dominasi agama, dominasi negara, atau keseimbangan antara agama dan negara. Karena itulah alMawardi (w. 1058 M) -yang meski pada masanya belum dikenal negara

38Bahtiar Effendy, Islam dan Negara ..., h. 15. 
kebangsaan- telah memiliki suatu pandangan bahwa penegakan negara merupakan tugas suci yang dituntut oleh agama sebagai salah satu perangkat untuk mendekatkan diri kepada Allah.

Inti pradigma ini adalah adanya hubungan simbiosis mutualisma atau hubungan yang saling menguntungkan dan saling melengkapi sehingga dapat secara bersama mempertahankan eksistensi masing-masing. Adapun pemrakarsa dari paradigma model simbiosis ini antara lain adalah Husayn Haykal (1888-1956), Muhammad Abduh (1849-1905), Fazlurrahman (19191988) dan Qamaruddin Khan.

Ketiga, secularistic paradigm (paradigma sekularistik); Paradigma ini merupakan bentuk penolakan terhadap kedua paradigma sebelumnya. Konsep ini menyatakan gagasan pemisahan agama dari negara (politik). Agama bukanlah dasar negara, tetapi agama lebih bersifat sebagai urusan individual semata. Penganjur aliran ini sejak lahirnya negara kebangsaan hingga saat ini, antara lain didominasi para pemikir dari Mesir, seperti Ali Abdur Raziq (1888-1872), Thaha Husein (1889-1973), Ahmad Lutfi al-Sayyid (1872-1963), dan terakhir adalah Muhammad Sa'id Asymawi (1932).

Ali Abdur Raziq menyatakan bahwa Islam adalah hanya agama dan tidak mencakup urusan negara. ${ }^{39}$ Sementara Thaha Husein, yang aktif menulis sejak tahun 50-an hingga 80-an, berpendirian bahwa baginya, agama itu merupakan persoalan dirinya dengan Tuhan. Lebih jauh ia berpandangan bahwa sejak dahulu konsep waḥdat al-dīn (kesatuan agama), waḥdat al-lughāt (kesatuan bahasa), dan waḥdat al-siyāsī (kesatuan politik), tidak dapat dijadikan dasar dan pilar bagi pembentukan pemerintahan. Di penghujung analisisnya ia menyatakan bahwa "sesungguhnya politik adalah sesuatu dan agama adalah sesuatu yang lain, dan sesungguhnya sistem pemerintahan dan pembentukan negara adalah atas dasar manfaat-manfaat amaliyah, bukan atas sesuatu yang lain"40

Mengkritisi pandangan Thaha Husein, Harun Nasution berpendapat bahwa proses-proses diri dari ikatan agama disebut sekularisasi, dan proses ini tidak hanya terdapat dalam masyarakat Barat, tetapi juga dalam masyarakat Islam. Sekularisasi di Barat membawa penganut agama

\footnotetext{
39Jaih Mubarak, Fiqh Siyasah, h. 58.

${ }^{40}$ Syahrin Harahap, Al-Qur'an dan Sekularisasi, Kajian Kritis terhadap Pemikiran Thaha Husein (Yokyakarta: Tiara Wacana, 1994).
} 
melepaskan diri secara total, dari seluruh ikatan agama, sehingga orang cenderung tidak beragama lagi, sementara dalam Islam pelepasan diri itu hanya dari ikatan-ikatan tertentu dari agama dan orang masih tetap beragama. Sekularisasi dalam Islam tidak sampai pada tahap dimana umat Islam merasa tidak lagi terikat dengan ajaran-ajaran dasar dan absolut, yang oleh karenanya ia meninggalkan agama. Dengan demikian sekularisasi dalam Islam hanya terjadi dalam ajaran-ajaran hasil ijtihad ulama, dan ini akan terus berjalan sesuai dengan perubahan zaman. ${ }^{41}$

Dari ketiga model paradigma relasi Islam dan negara di atas, tidaklah mudah menjatuhkan pilihan apakah model integralistik, simbisosis atau sekularistik yang tepat bagi bangsa Indonesia. Sebab sebagaimana sering dikemukakan oleh Bahtiar Effendy, bahwa masing-masing dari ketiga paradigma relasi -integralistik, simbiosis dan sekularistik- memiliki kelebihan dan kekurangan, artinya ketiganya saling melengkapi dalam kondisi-kondisi tertentu. ${ }^{42}$ Secara faktual, jika memilih salah satu dari tiga model atau paradigma relasi hubungan negara dengan Islam, misalnya model relasi simbiosis-mutualisme, maka peluang untuk memperjualbelikan harga komoditas politik dengan harga komoditas agama oleh praktisi-praktisi politik sangat mungkin dilakukan dan terbuka lebar. Oleh karenanya, patut dipertimbangkan dalam memberlakukan paradigma relasi Islam dan negara, agar baik negara maupun agama, keduanya tidak dikorbankan oleh sebuah idealisme paradigma tertentu.

\section{Merespons Politik Islam Kontemporer, Kini dan Esok}

Tantangan yang dihadapi negara-negara Muslim sangat banyak dan kompleks. Namun, harapan bahwa Islam dapat memberikan basis negarabangsa tidak dapat dan tidak harus dipatahkan begitu saja. Sebagaimana telah digambarkan sebelumnya bahwa Indonesia secara historis harus dipahami sebagai Indonesia yang mengawali persinggungan intelektualnya dengan dunia Barat melalui kolonialisme Portugis dan Belanda, sehingga kesan yang mendominasi otak bangsa Indonesia ketika itu adalah kolonialisme asing

\footnotetext{
41Harun Nasution, Islam Rasional; Gagasan dan Pemikiran, h. xiii-xiv

42Disampaikan dalam beberapa pertemuan kuliah program Doktor, mata kuliah "Isu-isu Islam Kontemporer" di UIN Syarif Hidayatullah antara bulan Oktober 2006 hingga Januari 2007.
} 
(Barat) yang negatif. Di sisi lain, ketika Indonesia bersentuhan secara intelektual hingga pada soal keyakinan kepada suatu agama dengan dunia Arab (maupun India) yang memperkenalkan agama Islam ke wilayah Indonesia membuat bangsa Indonesia memiliki kesan positif terhadap dunia Arab, khususnya bangsa Yaman, Saudi dan Mesir. 43

Kekayaan sejarah hubungan Islam dan negara di Indonesia seharusnya menjadi inspirasi dan pelajaran berharga untuk menentukan sikap dalam menghadapi tantangan masa depan. Perlu dikembangkan ke depan adalah pemikiran-pemikiran baru Islam politik atau politik Islam yang diharapkan mampu mengekspresikan nilai-nilai demokrasi, HAM, keadilan dan penegakan hukum, keterbukaan, kesetaraan gender, pluralisme, civil society, dan toleransi. Tema-tema inilah yang menjadi mainstream pemikiran dan praktik politik Islam. Nurcholis Madjid menyatakan bahwa dalam reformasi ini, Islam di Indonesia memang dituntut untuk mewujudkan nilai-nilai peradabannya, sebagaimana pernah terwujud dalam masa kesalehan Islam dan empat Khalifah pertama. Ia meyakini bahwa nilai-nilai Islam Indonesia akan membentuk wawasan kemodernan di Indonesia. ${ }^{4}$

Tipologi pemikiran politik Islam di Indonesia yang berkembang hingga saat ini baik secara formalistik, substantif, transformatif, totalistik, idealistik maupun realistik, yang dipandang sebagai respons positif dari cendekiawan Muslim Indonesia, sebagaimana diuraikan secara panjang lebar oleh M. Syafi'i Anwar, merupakan hal yang patut diteruskan sebagai pijakan secara proporsional. ${ }^{45} \mathrm{Hal}$ ini karena pada akhirnya proses-proses pembaruan pemikiran itulah yang diharapkan dapat memberi sumbangsih dan memberikan kontribusi positif dalam menyikapi problematika seputar Islam, politik dan negara, dalam kerangka kenegaraan dan kebangsaan Indonesia, baik saat ini maupun masa mendatang. Selain itu juga menghindarkan timbulnya konflikkonflik horisontal, seperti konflik agama atau identitas lainnya.

\footnotetext{
43Penyebaran Islam di Indonesia, berbeda dengan penyebaran Islam di wilayah Barat, Spanyol dan sekitarnya, membuat bangsa Barat memandang Islam sebagai kolonialis dan militeris, sehingga kesan mereka terhadap Islam berawal dari anggapan "negatif".

${ }^{44}$ Nurcholish Madjid, Cita-cita Politik Islam Era Reformasi (Jakarta: Paramadina, 1999), h. xvi.

45Lebih lanjut, mengenai tipologi pemikiran politik di Indonesia dapat di lihat dalam, Syafíi Anwar, Pemikiran dan Aksi Islam ..., h. 143-184.
} 
Beberapa pandangan dalam menyikapi perbedaan identitas terdiri dari: Pertama, pandangan primordialis. Kelompok ini menganggap, perbedaanperbedaan yang berasal dari genetikal seperti suku, ras, termasuk agama merupakan sumber utama lahirnya benturan-benturan kepentingan etnis maupun agama. Kedua, padangan kaum instrumentalis. Menurut mereka, suku, agama dan identitas lain seperti partai, ormas, dan sebagainya dianggap sebagai alat yang digunakan individu atau kelompok untuk mengejar tujuan yang lebih besar, baik dalam bentuk materil maupun non-materil. Konsepsi ini lebih banyak digunakan oleh politisi dan para elit untuk mendapatkan dukungan dari kelompok identitas. Dengan meneriakkan "Islam" misalnya, diharapkan semua orang Islam merapatkan barisan untuk mem-back up kepentingan politiknya. Oleh karena itu dalam pandangan kaum instrumentalis, selama berkenan mengalah dari preference yang dikehendaki elit, selama itu pula benturan antar kelompok identitas dapat dihindari dan tidak dapat terjadi.

Ketiga, adalah kaum konstruktivis yang beranggapan bahwa identitas kelompok tidaklah bersifat kaku, sebagaimana dibayangkan oleh kaum primordialis, atau sedemikian mudah diperalat oleh elit, sebagaimana pandangan kaum instrumentalis. Etnisitis bagi kelompok konstuktivis, dapat diolah hingga membentuk jaringan relasi pergaulan sosial-politik. Karenanya, etnisitis dan bentuk keragaman yang lain merupakan sumber kekayaan hakiki yang dimiliki manusia untuk saling mengenal dan memperkaya budaya. Bagi mereka, persamaan adalah anugerah dan perbedaan adalah berkah.

Relasi Islam dan negara perlu menyentuh permasalahan-permasalahan yang dinamis, baik dalam tataran keagamaan maupun kenegaraan, seperti penegakan hukum pidana dan perdata, sistem birokrasi, KKN, kemiskinan dan pengangguran, disamping isu-isu internasional seperti globalisasi, HAM, pluralisme, kesetaraan gender, fenomena terorisme dan sebagainya.

\section{Kesimpulan}

Beberapa kesimpulan penting yang dapat disampaikan dari pembahasan di atas sebagai berikut: Pertama, Islam dan negara sebagai wacana yang didominasi tema-tema politik dan ekonomi, baik bagi "negara" maupun bagi "agama", dapat dikaji dengan menggunakan berbagai pendekatan. Teori politik Islam tidak dimaksudkan untuk mendirikan negara agama atau negara Islam Indonesia, tetapi lebih pada pengisian ruang-ruang agama yang menjadi 
fungsional dalam tatanan kehidupan bermasyarakat, berbangsa dan bernegara. Kedua, relasi Islam dan negara dapat terintegrasi dalam garis-garis fungsional kedua terma, yang sama-sama mencita-citakan keluhuran. Bahwa model relasi integralistik, simbiosis dan sekularistik, masing-masing harus dipandang sebagai bentuk yang saling melengkapi. Ketiga, bahwa respons politik Islam Indonesia di era kontemporer harus diartikulasikan sebagai upaya untuk selalu menyesuaikan dengan perkembangan masyarakat dari berbagai aspeknya; globalisasi ekonomi-politik dunia, sains dan teknologi, perkembangan isu-isu demokrasi, gender, HAM, pluralisme, secara nasional maupun internasional.[a]

\section{DAFTAR PUSTAKA}

Ahmad, Amrullah, dkk, Dimensi Hukum Islam dalam Sistem Hukum Nasional, Jakarta: Gema Insani Press, 1996.

Ali, Muhammad Daud, Hukum Islam, cet. XII, Jakarta: Raja Grafindo, 2004.

Anwar, M. Syafi'i, Pemikiran dan Aksi Islam Indonesia, Jakarta: Paramadina, 1995.

Arifin, Bustanul, Pelembagaan Hukum Islam di Indonesia, Jakarta: Gema Insani Press, 1996.

Aulawi, Wasit, "Kompilasi Hukum Islam dalam Sistem Hukum Nasional", Pidato Pengukuhan, IAIN Jakarta, 1989.

Azra, Azyumardi, Islam Substantif; Agar Umat tidak Jadi Buih, ed. Idris Thaha, Bandung: Mizan, 2000.

Bisri, Cik Hasan, Peradilan Agama di Indonesia, Jakarta: Raja Grafindo Persada, 1996.

Boullata, Issa J., Dekonstruksi Tradisi, Gelegar Pemikiran Arab Modern, cet. I, Yogyakarta: LKIS, 2001.

Djazuli, A., Fiqh Siyasah; Implementasi Maslahat Umat dalam Rambu-Rambu Syari'ah, Bandung: Gunung Djati Press, 2000.

Donohue, John J. dan John. L. Esposito, Islam dan Pembaharuan, cet. V, Jakarta: Raja Grafindo Persada, 1995.

Effendy, Bahtiar, Islam dan Negara: Transformasi Gagasan dan Praktik Politik Islam di Indonesia, Jakarta: Paramadina, 2009.

Effendy, Bahtiar, dan Fachri Ali, Merambah Jalan Baru Islam, Bandung: Mizan, 1986. 
Hamsah Hasan

Esposito, John L., Islam dan Politik, Jakarta: Bulan Bintang, 1990.

Harahap, Syahrin, al-Qur'an dan Sekularisasi, Kajian Kritis terhadap Pemikiran Thaha Husein, Yogyakarta: Tiara Wacana, 1994.

Himpunan Fatwa Majelis Ulama Indonesia, 2003.

Imārah, Muhammad, al-Islām wa al-Sulțat al-Dīniyyah, cet. II, Beirut: Mu'assasat al-'Arabiyyah wa al-Nashr, 1980.

Khallaf, Abdul Wahab, Politik Hukum Islam, terj. Zainuddin Adnan, Yogyakarta: Tiara Wacana, 1994.

Kuntowijoyo, “Agama Berdimensi Banyak, Politik Berdimensi Tunggal”, dalam Abu Zahrah (ed.), Politik Demi Tuhan, Bandung: Pustaka Hidayah, 1999.

Madjid, Nurcholish, Cita-cita Politik Islam Era Reformasi, Jakarta: Paramadina, 1999.

Mubarak, Jaih, (ed.), Peradilan Agama di Indonesia, Bandung: Pustaka Bani Quraisy, 2004.

Nasution, Harun, Islam Rasional; Gagasan dan Pemikiran, cet. V, Bandung: Mizan, 1998.

Natsir, Mohammad, Capita Selecta, Jakarta: Bulan Bintang, 1973.

Natsir, Mohammad, Islam Sebagai Dasar Negara, Jakarta: Dewan Da'wah Islamiyah Indonesia, 2000.

Noer, Deliar, Pemikiran Politik di Negeri Barat, Cet. I, Bandung: Mizan, 1971.

Raharjo, Dawam, "Agama Masyarakat dan Negara”, dalam Agama dalam Pergumulan Masyarakat Kontemporer, Mukti Ali, dkk, Jakarta: Tiara Wacana, 1998.

Rumadi, "Agama dan Negara; Dilema Regulasi Kehidupan Beragama di Indonesia”, dalam Istiqra', Jurnal Penelitian Ditpertais, Vol. 04, No. 01, 2005.

al-Shahrastanī, Abū al-Fatḥ Muhammad 'Abd al-Karīm ibn Abī Bakr Aḥmad, alMilal wa al-Nihal, Kairo: Bāb al-Halabī, 1967.

Ṭālib, Șūfì Hasan Abū, Taṭbīq al-Sharī'at al-Islāmiyyah fi l-Bilād al-'Arabiyyah, Kairo: al-Nahdiah, 1995.

UUD '45 dan Amandemennya 1999, 2000, 2001 dan 2002, di bawah Kabinet Indonesia Bersatu, Jakarta: Fokus Media, 2006.

Wahid, Marzuki, dan Abd Maqsith Ghazali, "Relasi Agama dan Negara”, dalam Istiqra', Jurnal Penelitian Ditpertais, Volume 04, Nomor 01, 2005. 